\title{
Analysis of Motivation, Knowledge and Investment Education on Investment Interest in Capital Market
}

\author{
Kurniawan Patma, Maylen K.P. Kambuaya, Rama Soyan Arunglamba, Hesty T. Salle \\ Universitas Cenderawasih, Jayapura, Papua, Indonesia \\ Email: patmakurniawan@gmail.com, kathrinpetra050585@ymail.com ramasoyan.al@gmail.com \\ salle.hesty@gmail.com
}

\begin{tabular}{|c|c|}
\hline ARTICLE INFO & ABSTRACT \\
\hline $\begin{array}{l}\text { Received } \\
23 \text { Juny } 2021 \\
\text { Revision } \\
1 \text { July } 2021 \\
\text { Approved } \\
10 \text { July } 2021 \\
\text { Keywords: } \\
\text { Investment motivation } \\
\text { Investment knowledge } \\
\text { Investment education } \\
\text { Investment interest }\end{array}$ & $\begin{array}{l}\text { The purpose of this study is to determine and analyze the effect of } \\
\text { investment motivation, investment knowledge on investment } \\
\text { interest, investment education on investment interest in the capital } \\
\text { market for students of the Faculty of Economics and Business, } \\
\text { Cenderawasi University. The population taken in this study were } \\
\text { students of the } 2016 \text { FEB Uncen Accounting Study Program and the } \\
2017 \text { class. The knowledge variable affected the investment interest } \\
\text { of the } 2016 \text { FEB Uncen Accounting Study Program students and the } \\
2017 \text { class. Accounting FEB Uncen class 2016, class } 2017 \text { and class } \\
2018 \text {. }\end{array}$ \\
\hline
\end{tabular}

\section{INTRODUCTION}

The rapid development of economic and communication technology in Indonesia provides so much ease in the world of business and investment. Investment has an important role in the economic development of a country. according to (Raditya, Budiarta, \& Suardikha, 2014) there are two paradigms regarding investment that apply in today's society, namely, First, investment is considered as a desire and second investment is considered as a necessity. Basically the development of technology today also provides facilities for the public to freely choose how to invest. Information on the types and ways of investing is available so abundantly especially with the presence of internet media.

Along with the development of the investment world, the general public began to know financial investment, one form of investment that is often used is investment in the capital market (Wibowo, 2019). Education about the capital market to the public is important because it is useful to increase the number of enthusiasts to invest in the capital market (Tandio \& Widanaputra, 2016). Therefore, the government in cooperation with the Indonesia Stock Exchange (IDX) as the manager of securities sales in Indonesia makes efforts to continue to increase public interest in investing in the capital market. One of the efforts of the Indonesia Stock Exchange (IDX) to boost the number of investors is through the "Yuk Nabung Saham" program. This campaign is intended to change the habits of Indonesian people from saving habits to investing, so that Indonesians begin to move from saving society to investing society. In addition to the "Yuk Nabung Saham" campaign, IDX also held a socialization and education program on investment in the capital market, namely the "Capital Market School" (SPM) program where the program is directly educated to the public through socialization small scale that is told by academics or students and students to a larger scale that is in the community in general.

Since 2010 PT Bursa Efek Indonesia (IDX) has collaborated with The Higher Education and Securities Company to place Investment Galleries in various universities as

\footnotetext{
How to cite:

Patma, Kurniawan, Maylen K.P. Kambuaya, Rama Soyan Arunglamba, Hesty T. Salle (2021) Analysis of Motivation, Knowledge and Investment Education on Investment Interest in Capital Market. Jurnal of Social Science 2(4). https://doi.org/10.46799/jss.v2i4.173

E-ISSN: 2721-5202

Published by: Ridwan Institute
} 
a gym to introduce the capital market since itself to students, students and the surrounding community. This investment gallery not only provides an understanding of the capital market in theory, but also provides an opportunity to simulate and transact directly and willingly time (IDX, 2019).

Cenderawasih University, is one of the state universities that has had an investment gallery (corner of the exchange), the opening of this gallery in cooperation between the Faculty of Economics and Business of Cenderawasih University and the Financial Services Authority (OJK) and PT. Phintraco Securitas. Students can start investing in several sectors, one of which is in the capital market in order to have better financial conditions in the future. As a student, funding is often the main obstacle in making investments If seen in general the financial resources of students can be obtained from the provision of parents, scholarships, and income from side jobs.

The interest in student investment is quite high, especially at the beginning of learning, but not a few of the students who undo their intentions when the theory studied in college is demonstrated in the real world. There are many factors that influence why this happens, among others are the lack of remaining pocket money that can be used to invest, the lack of time to conduct and supervise transactions, and limited investment education. Although with the learning about the basic knowledge of investment provided to students and supporting facilities in the form of corner exchanges and various seminars, it is still not able to measure the level of interest and also the motivation of students to jump directly in investing in the capital market. Therefore, this study aims to measure how much influence students motivation, knowledge and education to invest in the capital market.

Based on the explanation above, the author is interested to conduct research with the title "Influence of Motivation, Knowledge and Investment Education on Investment Interest in Capital Market in Students of Faculty of Economics and Business, University of Cenderawasih". The purpose of this study is to obtain empirical results on: 1) the influence of investment motivation on investment interests in the capital market, 2) the influence of investment knowledge on investment interests in the capital market, 3) the influence of education on interests investment in the capital market, and 4) the influence of motivation, knowledge and investment education on investment interest in the capital market.

\section{METHOD}

This research is a causality study, which aims to determine the relationship and influence between two or more variables (Indriantoro \& Supomo, 2014). The research was conducted at the Faculty of Economics and Business, Cenderawasih University. The population in this study is students of Accounting Study Program class of 2016, 2017 and 2018, with sampling techniques using purposive sampling. Sugiyono (2012) purposive sampling is a sampling technique with certain considerations. In this study, several criteria were submitted by researchers as samples.

Data collection techniques through online questionnaires are shared using google form. Data analysis using SPSS (Statistical Package For Social Science) program.

\section{RESULTS AND DISCUSSION}

\section{A. Data Analysis}

Of the 128 respondents who filled out questionnaires online, there were 90 questionnaires or $70.32 \%$ that could be processed, while the remaining $29.68 \%$ could not be processed because they were incomplete.

Based on validity tests conducted with pearson correlation, it was obtained that all indicators in the variables studied were declared valid with significance values $<0,05$. Then from the results of reliability test with Cronbach Alpha formula, obtained the result that all variables in the study were declared raliabel with cronbach alpha value $>0,06$.

Table 1

Reliability Test

\begin{tabular}{ccc}
\hline $\begin{array}{c}\text { Variable } \\
\text { Research }\end{array}$ & $\begin{array}{c}\text { Cronbach } \\
\text { Alpha }\end{array}$ & Information \\
\hline $\begin{array}{c}\text { Investment } \\
\text { Motivation }\end{array}$ & 0,772 & Reliabel \\
\hline $\begin{array}{c}\text { Investment } \\
\text { Knowledge }\end{array}$ & 0,741 & Reliabel \\
\hline $\begin{array}{c}\text { Investment } \\
\text { Education }\end{array}$ & 0,766 & Reliabel \\
\hline
\end{tabular}




\begin{tabular}{ccc}
\hline $\begin{array}{c}\text { Investment } \\
\text { Interest }\end{array}$ & 0,761 & Reliabel \\
\hline
\end{tabular}

After the validity test and reliability test, a classic assumption test is conducted which is a condition in data analysis techniques using SPSS. Classic assumption tests performed are normality tests,multicolinearity tests and heterokesdastisity tests. Based on the results by the data it is stated that all classic assumption tests have been met.

Based on the results of the regression analysis obtained the results that each independent variable, namely investment motivation, investment knowledge and investment education affects the minar of investment in the capital market, with a significance value of $<0.05$. The value of Adjusted $R$ Square is 0.408 or $40.8 \%$, which means that independent variables are able to explain dependent variables by $40.8 \%$ and the remaining $59.2 \%$ is explained by other factors outside of this study.

\section{B. Hypothesis Test}

Regression model testing is used to determine whether independent variables that make up a regression model have a significant influence on dependent variables. This test was conducted to test whether the investment motivation variable (X1) and investment knowledge (X2) investment education (X3) to investment interest ( $Y$ ). To test the relationship, a t-test is used, i.e. by comparing the value of the thitung with tabel. Independent variables forming regression models are said to have a significant effect if thitung $>$ tabel or a significant degree of $<$ $a=0,05$.

Based on the test results with the help of SPSS 21 software, it was obtained that the investment motivation has a significance value of $0.011<0.05$ which means that $\mathrm{H} 1$ is accepted. Then the investment knowledge variable obtained significance value of $0.004<0.05$ so that it can be concluded that $\mathrm{H} 2$ is accepted. Similarly, the variable investment education obtained a significance value of $0.002<0.05$, which means $\mathrm{H} 3$ is accepted.
1. The Effect Of Investment Motivation On Investment Interest In The Capital Market

Based on the results of data analysis, it is known that the value of statistic $t$ test against investment motivation variable $\left(X_{1}\right) 2,605$ with a significance rate of 0.011 . This test shows that $\mathrm{H}_{a}$ accepted so that it can be concluded that investment motivation has a significant effect on investment interest in students of accounting Prodi FEB Uncen class of 2016, class of 2017 and class of 2018. The results of this study are in line with the results of the Hidayat, Muktiadji, \& Supriadi (2019) that the knowledge of investing in a person has an effect on the interest in investing.

In general, people will take an action if there is a something that interests him so that naturally the person will be motivated to obtain it. In the business world, there are many things that can encourage someone to be motivated to join the business activities. One of them is the return or profit offered. In addition to return or depression, another thing to consider is the inhibitory factor that is the possibility of problems and risks that will be faced in the future. This risk factor is the consideration of prospective investors to be able to invest or not invest in the capital market. Therefore, in this study, students were given questionnaires in the form of questions about return and also the risk of investing as a consideration.

2. The Influence of Investment Knowledge on Investment Interest in The Capital Market

From the results of data analysis, it is known that the statistical value of $t$ test variable investment education $\left(\mathrm{X}_{3}\right)$ 2,330 with a significance rate of 0.022 . This test shows that $\mathrm{H}_{\mathrm{a}}$ accepted so that it can be concluded that investment knowledge has a significant effect on investment interest in students of feb uncen accounting program class of 2016, class of 2017 and class of 2018.

The results of this study are in line with the results of the Merawati \& Putra (2015) which states that investment knowledge and income 
have a positive effect on students' intention to invest in the capital market. Agree with the results of the study Wijayanti (2015) which states that knowledge affects the interests of students to invest.

Knowledge or education about investment is absolutely necessary for a potential investor before entering the world of capital markets or business. This adequate knowledge will shape one's ability to create value and profit and also be able to manage an existing risk both small and large so as to reduce the impact of losses that will be experienced (Prayoga, 2019). For students, especially accounting students who have studied portfolio and financial management, of course it has become one of the basic foundations and also capital to be able to join the world of capital market investment.

\section{The Effect of Investment Education on Investment Interest in The Capital Market}

From the results of data analysis, it is known that the statistical test value of $t$ against competency variables $\left(X_{2}\right)$ obtained test statistics of 3,602 with a significance rate of 0.001 . This test shows that $\mathrm{Ha}$ was accepted so that it can be concluded that investment education has a significant effect on investment interest in students of FEB Uncen accounting program class of 2016, class of 2017 and class of 2018.

The first indicator on education is to increase the number of new investors. The Capital Market School gave a positive result as it increased the number of new investors in the capital market. With the Capital Market School can provide knowledge about the capital market and how to invest in the capital market for potential new investors. The second indicator on education is important to get capital market education first. The Capital Market School gives positive results because it is important for potential investors to get education first. Education is very important for potential investors to invest in the capital market so that prospective investors know how to invest and what types of investments are in the capital market.

The third indicator in education is to provide knowledge about investments in the capital market. The Capital Market School gives positive results because it provides knowledge about the capital market. By investing in the capital market investors gain a lot of knowledge and benefits in the capital market. One of them is to increase economic growth in Indonesia. The fourth indicator in education is to provide information to participants to intelligently manage their finances. The Capital Market School provides positive results because it provides information to participants to intelligently manage finances. The participants of the Capital Market School were given several discussion materials, namely how to invest, types of investments, and smartly manage finance. By participating in the Capital Market School, it is expected that investing in the capital market of the participants can be smart in managing finances.

Investment education is a very important need for a person to start investing, so that it should be a business in fostering systematic and quality education development needs to continue to be strived, so that the purpose of the divestment process can be achieved optimally. Education is also applied in the world of investment, which aims to provide learning and a broader understanding of investments and risks to potential investors. Education in the investment world is known as the Capital Market School (SPM). Sekolah Pasar Modal (SPM) is an educational and socialization program organized periodically by the Indonesia Stock Exchange (IDX) (Saputra, 2018).

\section{CONCLUSION}

Investment motivation affects the investment interest of accounting students in the class of 2016, 2017 and 2018. This means 
that potential investors will be interested in investing if their partners, relatives and environment have invested in the capital market.

Investment knowledge affects the investment interest of accounting students in the class of 2016, 2017 and 2018. This means that a potential investor must have basic knowledge before making an investment.

Investment education has an effect on the investment request of accounting students in the class of 2016, 2017 and 2018. This means that education or socialization about investment in the capital market is very interesting.

\section{REFERENCES}

Annonim. (2015). 7 hal yang harus Anda pertimbangkan sebelum berin vestasi di saham.

Audriene, D. (2016). BEI Bidik Mahasiswa Sebagai Investor Saham Baru. Diunduh pada tanggal 28 November 2016 dari http://www.cnn indonesia.com/ekonomi/2016051718041 7-78-131405/bei-bidikmahasiswasebagai-investor-saham-baru/.

Hidayat, L., Muktiadji, N., \& Supriadi, Y. (2019). Pengaruh Pengetahuan Investasi Terhadap Minat Mahasiswa Berinvestasi Di Galeri Investasi Perguruan Tinggi. JAS-PT (Jurnal Analisis Sistem Pendidikan Tinggi Indonesia), 3(2), 63-70. Google Scholar

IDX. (n.d.). Data Galeri Investasi BEI (per Maret 2019). Retrieved from 2019 website: http://www.idx.co.id

Indriantoro, N., \& Supomo, B. (2014). Metodologi Penelitian Bisnis. BPFE Yogyakarta.

Merawati, L. K., \& Putra, I. P. M. J. S. (2015). Kemampuan Pelatihan Pasar Modal Memoderasi Pengaruh Pengetahuan Investasi Dan Penghasilan Pada Minat Berinvestasi Mahasiswa. Jurnal IImiah Akuntansi Dan Bisnis. Google Scholar

Prayoga, Y. (2019). Pengaruh Edukasi Dan Sosialisasi Sekolah Pasar Modal Bursa
Efek Indonesia Terhadap Motivasi Membeli Saham Di Galeri Investasi Universitas Labuhan Batu. ECOBISMA (Jurnal Ekonomi, Bisnis Dan Manajemen), 6(2), 137-144. Google Scholar

Raditya, D., Budiarta, I. ., \& Suardikha, I. M. S. (2014). Pengaruh Modal Investasi Minimal di BNI Sekuritas. Ekonomi, 7, 377-390. Google Scholar

Rayanti, D. (2016). BEI Ajak Mahasiswa 'Nabung Saham' Sejak Dini

Saputra, D. (2018). Pengaruh Manfaat, Modal, Motivasi dan Edukasi Terhadap Minat Dalam Berinvestasi di Pasar Modal. Future: Jurnal Manajemen Dan Akuntansi, 5(2), 178-190. Google Scholar

Simamora, E. (2014). Minat Mahasiswa Berinvestasi di Pasar Modal Meningkat.

Sugianto, D. (2016). BEI Ingin Mahasiswa Sisihkan Rp100 Ribu untuk Investasi.

Sutikno, M.R. (2014). Pentingnya Memiliki Tujuan Keuangan Dalam Berinvestasi.

Sugiyono. (2012). Metode Penelitian Kuantitatif, Kualitatif, dan R\&D (16th ed.). Bandung: Alfabeta.

Suwartono. (2014). Dasar-dasar Metodologi Penelitian. Yogyakarta: Andi Offset

Tandio, T., \& Widanaputra, A. (2016). Pengaruh Pelatihan Pasar Modal, Return, Persepsi Risiko, Gender, Dan Kemajuan Teknologi Pada Minat Investasi Mahasiswa. E-Jurnal Akuntansi, 16(3), 2316-2341. Google Scholar

Wibowo, A. (2019). Pengaruh Pengetahuan Investasi, Kebijakan Modal Minimal Investasi, dan Pelatihan Pasar Modal terhadap Minat Investasi (Studi Kasus Mahasiswa FE UNESA yang Terdaftar di Galeri Investasi FE UNESA). Jurnal IImu Manajemen (JIM), オ1). Google Scholar

Wijayanti, R. (2015). Pengaruh Modal Minimal 
Investasi, Promosi Dan Pengetahuan

Terhadap Minat Mahasiswa Berinvestasi

Dinar di Gerai Dinar BMT Daarul

Mustaqiim Pekalongan. STAIN

Pekalongan. Google Scholar

\section{Copyright holder :}

Kurniawan Patma, Maylen K.P. Kambuaya, Rama Soyan Arunglamba, Hesty T. Salle (2021)

First publication right :

Journal of Social Science

This article is licensed under:

(c) (i) (2) 